\title{
DEVELOPMENT OF RESOURCE-SAVING AND ENVIRONMENTALLY SAFE BERYLLIUM BRONZE SOLDERING TECHNOLOGY
}

\author{
Stanislav Berezhnyy; Oleksii Kapustian; Ruslan Kulykovskyi; Ihor \\ Avdeev; Danylo Uriekin
}

\author{
Zaporizhzhia Polytechnic National University, Zaporizhzhia, Ukraine
}

\begin{abstract}
Summary. The composition of the solder, which provides the necessary technological properties of the product, namely, electrical conductivity and mechanical strength of the junction was selected. The possibility of brazing beryllium bronze with a silver contact plate by furnace brazing using fluxes based on $\mathrm{NaCl}: \mathrm{CaCl}_{2}: \mathrm{CaF}_{2}$ salts, respectively (24: 61: 15\% mass) in the atmosphere was established. The possibility of brazing BrB2 beryllium bronze in the atmosphere using a research flux based on the eutectic of the $\mathrm{NaCl}-\mathrm{CaCl}_{2}$ system (28...72\% wt.) adding $15 \% \mathrm{CaF}_{2}$ over a copper layer is shown. The technology for brazing beryllium bronze BrB2 with silver contact plates with silver solder PSr68 has been developed. The brazing process is combined with the hardening operation, which allows avoiding additional thermal operations; flux residues are removed during hardening and do not actually need additional cleaning operations; applied solder, flux components and technologies for applying a layer of copper are not scarce and relatively cheap, which can significantly reduce the cost of the product, subject to the requirements of the technical specifications. A technological process that makes it possible to refuse of using vacuum systems and toxic fluxes has been developed.

Key words: beryllium bronze; brazing; silver solder; flux; technological coating; resource-saving technology; environmental safety.
\end{abstract}

Statement of the problem. The basis of electric energy is integrated energy system of the country, the operation of which comprises more than 1 million kilometers of the electric supply lines [1]. The power field of Ukraine is getting worse. The system of providing upgrading and replacing of its components is not available [2]. Taking into account the importance of providing the reliable operation of electric supply [3] one of the foremost tasks of providing the country power safety is the problem of creation the systems of producing and supplying electric energy for upgrading of the power system of the country using up-to-date materials and technologies.

Networks with voltage up to $35 \mathrm{kV}$ are common in Ukraine [4]. Disconnectors of the RG series are intended for switching on and off sections of live electrical circuits, as well as grounding sections with grounding conductors. Disconnectors are also used to turn off the noload currents of transformers and charging currents of overhead and cable lines. To produce high-precision contact pairs of disconnectors, beryllium bronze $\mathrm{BrB} 2$ (copper $(\mathrm{Cu})-97.5 \%$, beryllium (Be) $2 \%$, nickel (Ni) $0.5 \%$ ) is used. This alloy is applied due to its physical and mechanical properties such as: low electrical resistance, high thermal conductivity, no sparks on impact, increased corrosion resistance, ability to harden and age at which the metal acquires the necessary mechanic properties. The alloy has a high level of wear, creep, fatigue resistance and a high elasticity limit retains its mechanical properties when heated strongly, at the 
temperature of $540^{\circ} \mathrm{C}$. The peculiarity of this bronze is that with a temperature change, the solubility of its alloying elements changes. In the solid solution during quenching from a singlephase zone, there is an increase in the number of atoms of alloying additives. This solution is unstable from the point of view of thermodynamics, so it decomposes at the slightest conditions change in. As temperatures rise, this process accelerates. Therefore, the hardening effect depends on the dispersion of the selected particles, which are formed during the decomposition of the solution. The temporary resistance to plastic deformation for BrB2 is $450 \mathrm{MPa}$, and after hardening it increases almost 2 times by $40 \%$, but if the metal is artificially aged, its resistance to temporary deformation will reach $1400 \mathrm{MPa}$ [5]. For this particular reason these alloys are used in the manufacture of springs, a safe tool that does not generate sparks on impact, and in electronics.

The presence of a stable oxide on the beryllium bronze surface, which is easily formed in air and is difficult to remove, does not allow its direct use as a contact element. The contact surface burns, the thickness of the oxide film increases and the stability of the contact is negative. Therefore, most frequently, silver contact plates brazed with silver solders are used. The use of silver solders, in this case, is due to the provision of low transient resistance between the silver contact plate and the body of the contact element $[6,7]$.

The main problem in brazing beryllium bronze is stable beryllium oxide. Therefore, most often brazing with silver solders is carried out in vacuum with mechanical pre-cleaning of the surface, followed by acid treatment. This method of soldering gives the best results, but requires complex equipment, which is not available at many enterprises. Another method is brazing with silver solders in a protective argon atmosphere or in a furnace using fluxes, which must contain fluoride salts of $\mathrm{CaF}_{2}$ and tetrafluoroboral potassium $\mathrm{KBF}_{4}$ [4]. The disadvantage of this method is the toxicity of such a flux, because potassium tetrafluoroborate decomposes when heated to above $750^{\circ} \mathrm{C}$ together with forming toxic gaseous fluoride borate BF3.

When producing the power contact of a high-voltage disconnector with a silver contact plate, the problem of affordable and safe way to solder beryllium bronze with silver plates arose.

Objective of the research. Developing of the technological process of manufacturing soldered high-voltage power contact of a disconnector from beryllium bronze and silver contact plate. Working out of flux composition and furnace soldering technology without the use of vacuum and protective atmosphere.

Results of the research and verification of the obtained scientific results. The power contact of the high-voltage disconnector is a contact rod made of beryllium bronze in which a silver contact plate is brazed into the milled groove (Fig. 1).

The contact plate is made of SrM95 alloy, designed for the manufacture of sliding and breaking contacts (Fig. 2 a). Melting point $\mathrm{Tm}=870 \ldots 910^{\circ} \mathrm{C}(\mathrm{GOST} 6836-2002)$.

The properties of the joints are determined by the parameters of the soldering process, the chemical composition and the initial state of the solder used [8].

The solder during brazing was used in the form of a plate with a thickness of $0.2 \ldots 0.25 \mathrm{~mm}$, the size of which corresponded to the size of the silver contact plate, Figure $2 \mathrm{~b}$.

The very low temperature interval between the melting of the silver contact plate and the silver solders requires careful selection of the latter - the soldering temperature (Tsoldering) must be under $870^{\circ} \mathrm{C}$ to avoid melting of the contact, also, the solder must have a low electrical resistance $(\rho)$.

If the base metal after soldering must be heat treated, then the total heating of the unit must use solder with a soldering temperature higher than the heat treatment temperature [9]. 
The tempering temperature of beryllium bronze is $\mathrm{BrB} 2760-780^{\circ} \mathrm{C}$. Therefore, the following solders were selected for the study [6]:

$\mathrm{PSr} 72$ : Tsoldering $=780 \ldots 900^{\circ} \mathrm{C}$;

PSr68: Tsoldering $=770 \ldots 870^{\circ} \mathrm{C}, \rho=14 \times 10-8 \mathrm{Ohm} \cdot \mathrm{m}$;

PSr62: Tsoldering $=760 \ldots 850^{\circ} \mathrm{C}, \rho=22 \times 10-8 \mathrm{Ohm} \cdot \mathrm{m}$.

A necessary condition for obtaining high-quality adhesion of solder to metal is wetting the metal surface with fluid solder [10]. It is known that to improve the spreading of solders during soldering, a freshly applied coating layer (galvanic, thermal vacuum and other methods) may be used on the surface of the product, which forms a eutectic with metal, brazed at the melting point lower than the melting point of the solder [7]. It is proposed to use copper as a pre-coating. A layer of copper makes it possible to prevent the bronze surface from oxidation when heated until the flux melts. In addition, the copper on the surface enables reducing the beryllium oxide concentration in the surface layers of the product, which will also be improved by wetting of the bronze surface with solder.

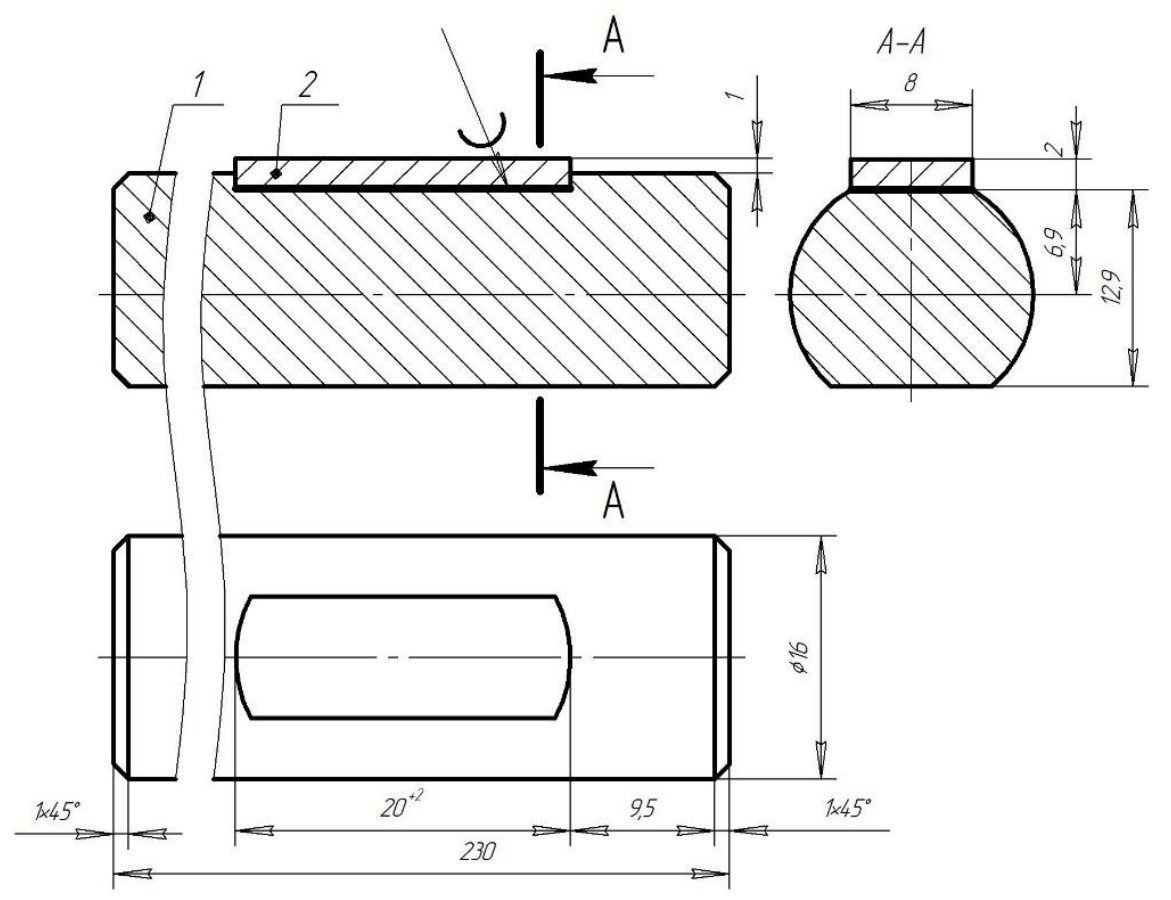

Figure 1. Power contact of the high-voltage disconnector: 1 - contact rod; 2 - silver contact plate

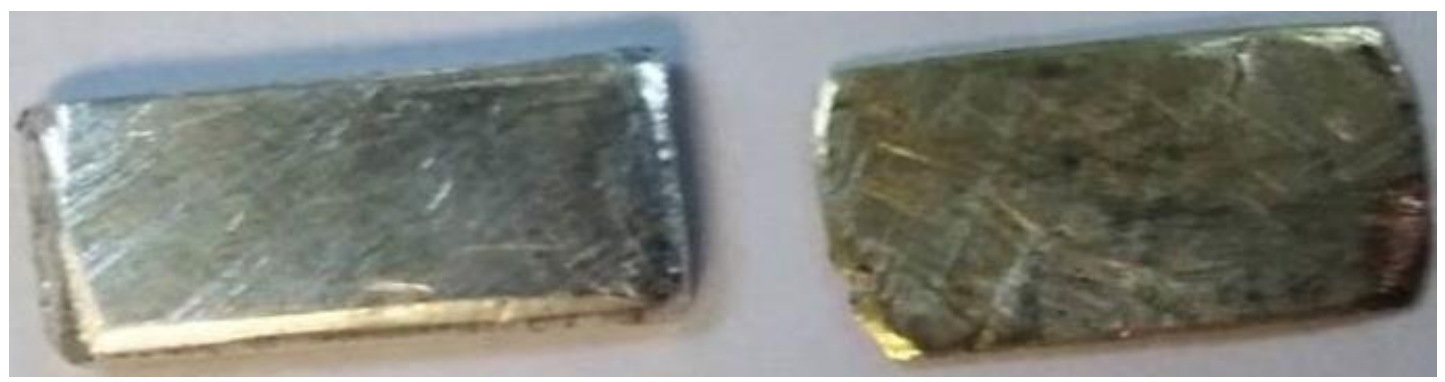

Figure 2. Plates: $\mathrm{a}$ - silver contact, $\mathrm{b}$ - solder 
The composition of the flux should be active and fluid at the soldering temperature, which in this case should not exceed $850^{\circ} \mathrm{C}$ to avoid contact melting of the thin silver plate.

Solder plates were made by rolling the solder wire into a strip and then cutting to the required size.

Flux was made from chemically pure components of calcium chloride $\left(\mathrm{CaCl}_{2}\right)$, sodium chloride $(\mathrm{NaCl})$ and calcium fluoride $\left(\mathrm{CaF}_{2}\right)$ salts. In a furnace at crucible temperature of $700^{\circ} \mathrm{C}$ a portion of dehydrated $\mathrm{CaCl}_{2}$ was melted, a portion of dried $\mathrm{NaCl}$ salt was added and after melting it, a portion of $\mathrm{CaF}_{2}$ was put. After cooling to $60^{\circ} \mathrm{C}$, the flux was crushed and sieved hot through a sieve of $-0.25+0.14 \mathrm{~mm}$, and immediately placed in an airtight beaker because calcium fluoride has significant hygroscopicity.

Parts for brazing were prepared as follows. In order to remove beryllium oxide, the contact surface was cleaned mechanically, then treated with hydrofluoric acid. Then a sublayer of copper was applied.

The copper layer was obtained using the Odessa Experimental Plant of Medical Equipment device EZI-1. The device is designed for electrolytic sharpening of cutting tools, but its characteristics can be used for coating by electrolytic deposition. The copper layer was applied by anodizing in acid solution with following components: high-purity copper sulfate $\left(\mathrm{CuSO}_{4} \times 5 \mathrm{H}_{2} \mathrm{O}\right) 200 \ldots 250 \mathrm{~g} / \mathrm{l}$; sulfuric acid solution $\mathrm{H}_{2} \mathrm{SO}_{4} 60 \ldots 70 \mathrm{~g} / \mathrm{l}$. The operating temperature of the electrolyte was $18 \ldots 25^{\circ} \mathrm{C}$ [11]. The cathode output current of the electrolyte was $95 \ldots 98 \%$. The electrolyte was prepared with distilled water. The cathode current density was $2 \ldots 7 \mathrm{~A} / \mathrm{dm}^{2}$. Taking into account the surface area on which the coating was applied $0.12 \mathrm{dm}^{2}$, the cathode current was 0.24 A. Coating time was 40 minutes. During coating, electrolyte was mixed with a polymer bead. The deposition rate is $12.5 \ldots 12.9 \mu \mathrm{m} / \mathrm{h}$. As an anode, electrotechnical copper M00 GOST 859-2014 was used, as a cathode, a contact rod was immersed in an electrolyte solution to a depth of $40 \mathrm{~mm}$.

The surface was fluxed and soldered; tape and a silver contact plate, which was also treated with flux, were laid. Beryllium bronze BrB2 was brazed in a furnace SNOL-0,25 in atmosphere at a temperature of $850^{\circ} \mathrm{C}$ with solder PSr68 DSTU 19746-2015. After holding in the furnace during brazing, the part was removed, the silver contact plate was pressed with tweezers. After crystallization of the solder, the part was immediately deeped in water with temperature $780^{\circ} \mathrm{C}$ for quenching. The following next, artificial aging of the metal was carried out according to conventional technology: exposure in a furnace at $310^{\circ} \mathrm{C}$ for 2 hours. This heat treatment provided high strength and hardness of beryllium bronze, which were achieved by isolation from a supersaturated $\alpha$-solid solution of a metastable $\gamma^{\prime}$-phase, which strengthens the alloy [12]. Soldered products were finished by the method of mechanical cleaning with metal brushes.

The quality of the soldered joint was evaluated:

- visually;

- $\quad$ by mechanical test - by the method of chipping the contact plate under tangential impact load;

- electrical tests - measurement of transient resistance and test for heating by DSTU EN 62271-102:2016 p.6.4 and p.6.5 respectively.

Visually, the quality of the joint was estimated with the naked eye at a distance of $25 \mathrm{~cm}$ from the controlled surface at illumination of more than 500 lux.

Mechanical test. The contact rod was clamped in a vise, a chisel with a blade length of $20 \mathrm{~mm}$ or $25 \mathrm{~mm}$ and a sharpening angle of $70^{\circ}$ according to GOST 7211-86 was installed in the side surface of the silver plate and hammerred. In case of brittle fracture of the brazed joint, 
or in case of unsatisfactory brazing quality, the contact plate cracked. At high viscosity of the soldered joint, it was cut on the plate material, without breaking on the soldered seam. Herewith, to ensure reliable conduction of current, the contact area of the soldered seam between the silver contact plate and the disconnector body must be at least $70 \%$.

Electrical tests.

The resistance (voltage drop) of the connections was measured by the DC voltmeterammeter method with a precision digital multimeter Siglent SDM3055 at ambient temperature. The measuring current was taken equal to $100 \mathrm{~A}$ - not more than 0.3 of rated current $(1000 \mathrm{~A})$. The voltmeter wire was connected by pressing sharpened needles, which terminate the wires at the appropriate points of the current-carrying circuit. Measurement points were set at a distance of $2-10 \mathrm{~mm}$ from the contact joint along the current. Resistance was measured before and after heating tests. The permissible average resistance value should not exceed $90 \mu \mathrm{Ohm}$.

Heating tests during the rated current in the continuous mode were performed from three single-phase current transformers UTT6M, assembled in a three-phase circuit, with phase-byphase voltage regulation. The connection to the transformers was made from a flexible copper wire with a cross section of $2 \mathrm{~mm} \times 300 \mathrm{~mm}$. The temperature was measured using chromelcopel thermocouples (TCC) registrating of their readings with a Siglent SDM3055 multimeter and subsequent enumeration of the obtained values of thermoEMF in ${ }^{\circ} \mathrm{C}$ according to the TCC calibration tables. The cold TCC junction was placed in an ice tank. The air temperature was controlled by three thermocouples located at $1 \mathrm{~m}$ distance from the structure at the connection level, and was determined as the arithmetic value of the readings of these thermocouples. The tests were performed with a three-phase alternating current of $1000 \mathrm{~A}$ before the onset of the set thermal regime, when the temperature changed by no more than $1{ }^{\circ} \mathrm{C}$ per one hour. The duration of the tests was 6 hours. Atmospheric conditions were determined using a digital compact weather station SAM700BAR: ambient temperature $-26.6^{\circ} \mathrm{C}$, air pressure $-754 \mathrm{~mm}$ $\mathrm{Hg}$; precipitation $-44 \%$. Permissible temperature excess over the effective ambient temperature was $50-80^{\circ} \mathrm{C}$. The effective value of the ambient temperature was $40^{\circ} \mathrm{C}$.

Results. When using the flux recommended by the literature sources (dehydrated borax (sodium tetraborate $\left.\mathrm{Na}_{2} \mathrm{~B}_{4} \mathrm{O}_{7}\right)-50 \%$, boric acid $\left(\mathrm{H}_{3} \mathrm{BO}_{3}\right)-35 \%$, calcium fluoride $\left(\mathrm{CaF}_{2}\right)-$ $15 \%$ ) and solder PSr 72; (Tsoldering $=780 \ldots 900^{\circ} \mathrm{C}$ ) there was a complete melting of the contact plate. The flux covered the surface unevenly and did not form a continuous protective film (Fig. 3).

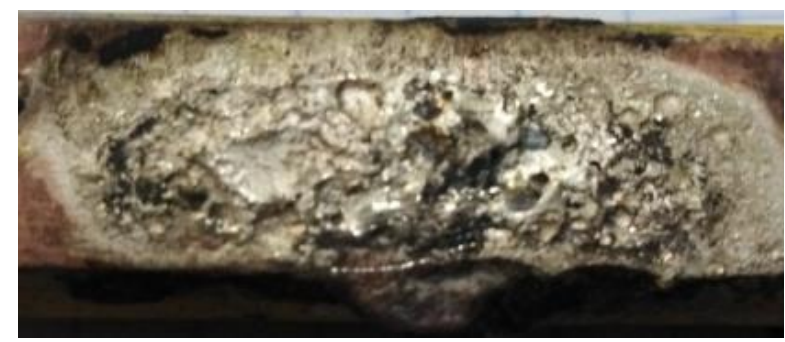

Figure 3. Sample brazed borate flux with $\mathrm{CaF}_{2}$

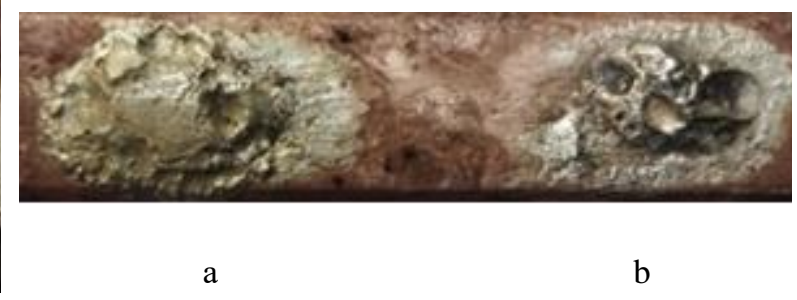

Figure 4. Technological test for spreading solders PSr62 (a) and PSr68 (b)

For brazing silver flux (boric anhydrite $\mathrm{BO}_{3}$ ) $-66 \%, \mathrm{Na}_{2} \mathrm{~B}_{4} \mathrm{O}_{7}-18 \%$ and $\mathrm{CaF}_{2}-16 \%$ ), Tsoldering $=800 \ldots 1000^{\circ} \mathrm{C}[6,7,13,14]$ is widely used. At the selected soldering temperature, this flux was very thick, did not form a continuous protective layer, in addition, was hard to remove after soldering. Other borax and boric anhydrite based fluxes had the same 
disadvantages. Therefore, there is a need to develop a non-toxic borate-free flux. After analyzing the literature data, we did not find a flux that would meet the following conditions: the presence of the fluoride salt $\mathrm{CaF}_{2}$, and soldering temperature Tsoldering $\leq 850^{\circ} \mathrm{C}$.

To determine the composition of the flux with a given melting point, the melting diagrams of salt-based systems were analyzed. As a flux, in this case, it was decided to use a salt mixture with a low melting point with the addition of fluoride salts. The existing readymade fluxes were only partially suitable for solving the problem $[6,7,13,14]$.

The experimental flux was developed on the basis of the eutectic composition of the $\mathrm{NaCl}-\mathrm{CaCl}_{2}$ system $(28 \%$ and $72 \%$ of the masses, respectively, melting point Tmelting $=494^{\circ} \mathrm{C}$ ) with the addition of $15 \% \mathrm{CaF}_{2}$. As established experimentally, the experimental flux $\mathrm{NaCl}: \mathrm{CaCl}_{2}: \mathrm{CaF}_{2}$, respectively (24: 61: 15 wt. \%) has Tmelting $=650^{\circ} \mathrm{C}$. At the soldering temperature Tsoldering $=800^{\circ} \mathrm{C}$ it was liquid, sufficiently wetted the surface of both beryllium bronze and silver contact plate.

It should be noted that the spreading of PSr62 solder while using the experimental flux is slightly higher than with PSr68 (Fig. 4 a). However, the contact plates brazed with PSr62 solder, in the presence of fillers and satisfactory appearance, were slightly chipped off during the tests due to the presence of tin $(\mathrm{Sn})-10 \%$. Therefore, we had to stop using solder PSr62.

The thickness of the applied copper layer was $8.0 \ldots 8.4 \mu \mathrm{m}$, with the recommended thickness of the copper layer applied by this method of $3 \mu \mathrm{m}$ [8]. The coating was dense, uniform with a smooth surface, Figure 5.

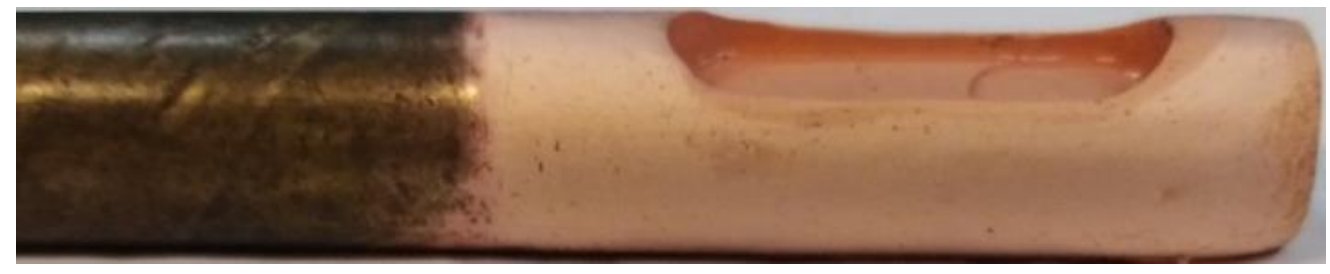

Figure 5. Technological coating of copper on the contact core of $\mathrm{BrB} 2$ alloy

The soldering temperature of $830^{\circ} \mathrm{C}$ and the holding time in the furnace for 9 minutes were selected experimentally.

Visual examining of the joint showed no oxidation and melting of the silver contact plate, as well as the absence of voids, undercuts, cracks, unsolders coming to the surface, general and local erosion. The solder formed smooth fillets, which indicates sufficient wetting of the surfaces.

Mechanical testing showed that the contact plates brazed with PSr68 solder during the tests were not chipped, but cut off the plate material under the applied tangential loads. The flat shape of the solder plate provided the contact area of the joint was not less than $90 \%$ by squeezing out of the gap of the flux, which fully satisfies the requirements of the technical task for the manufacture of high-voltage power contacts. On the basis of the developed technology, the experimental batch of power high-voltage contacts was made (Fig. 6).

Measured value of resistance of high-voltage power contacts, $\mu \mathrm{Ohm}$ :

- before heating test $68.3 \ldots 70.2$;

- after heating test 58.9...64.7.

The average resistance values met the requirement of less than $90 \mu \mathrm{Ohm}$, so the joints stood the test. 


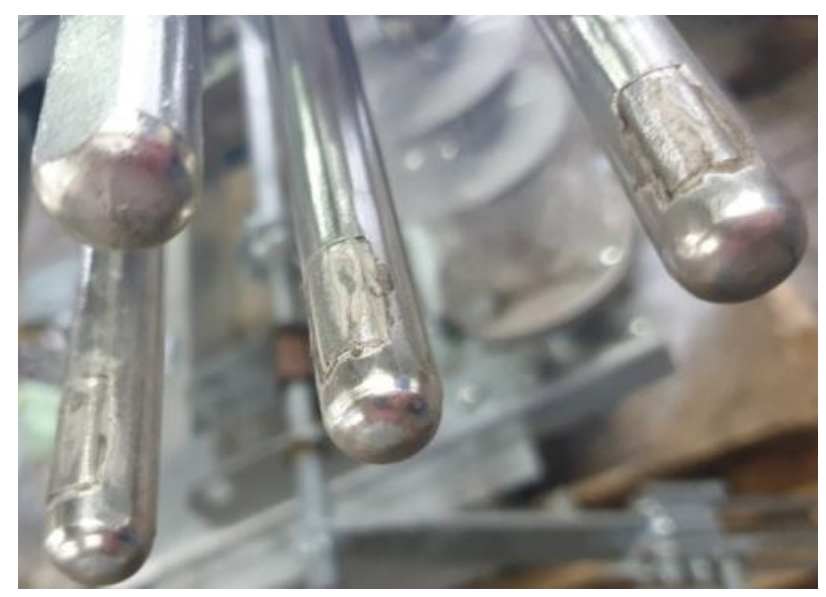

Figure 6. An experimental batch of soldered parts

The values of the maximum measured temperature exceedances in the steady state were $39.9 \ldots 48.7^{\circ} \mathrm{C}$. The difference in temperature exceeds at the joints and temporary joints at $1 \mathrm{~m}$ distance from the joint was not more than $5^{\circ} \mathrm{C}$. The temperature with taking into account the upper operating value of the ambient temperature was not higher than the set one, so the parts stood the test.

The possibility of brazing beryllium bronze $\mathrm{BrB} 2$ in the atmosphere using an experimental flux based on the eutectic system $\mathrm{NaCl}-\mathrm{CaCl}_{2}(28 \ldots 72 \%$ wt.) with the addition of $15 \% \mathrm{CaF}_{2}$ on a layer of copper with a thickness of $8.0 \ldots 8.4 \mu \mathrm{m}$ has been demonstrated.

The technology of soldering beryllium bronze $\mathrm{BrB} 2$ and silver contact plates with silver solder has been developed. The developed composition of the flux provides protective properties, wetting and spreading of PSr68 solder on the surface of beryllium bronze BrB2. The technological process of brazing is combined with the hardening operation, which makes it possible to avoid additional thermal operation and reduces the cost of manufacturing the highvoltage power contact of disconnector. The developed technological process allows to refuse from vacuum installations and toxic fluxes with the use of $\mathrm{KBF}_{4}$ tetrafluoroboral potassium. The process of soldering beryllium bronze can be carried out using common furnaces such as SNOL and the like. Residues of flux are removed during quenching and, in fact, do not require additional cleaning operations. The selected brazing temperature and solder composition allow to avoid melting of a thin silver contact plate and to preserve the initial state of its working surface. Solder, flux components and technologies for applying the technological layer of copper are not scarce and relatively cheap, which significantly reduces the cost of manufacturing the product when keeping the requirements of the technical task for the product.

Conclusions. 1. A resource-saving and ecologically safe soldering technology of beryllium bronze with preliminary application of a copper layer has been developed, using an experimental flux based on the eutectic of the $\mathrm{NaCl}-\mathrm{CaCl}_{2}$ system $(28 \ldots 72 \%$ by weight) with the addition of $15 \% \mathrm{CaF}_{2}$.

2. The composition of the solder, which provides the necessary technological properties of the product, namely, electrical conductivity and mechanical strength of the joint, has been selected.

3. The possibility of brazing beryllium bronze with silver contact plate by furnace soldering using fluxes based on $\mathrm{NaCl}: \mathrm{CaCl}_{2}: \mathrm{CaF}_{2}$ salts, respectively (24: $61: 15 \%$ by weight) in the atmosphere has been established. 


\section{References}

1. Kapustyanskyi A., Varlamov G. Analysis of the fuel and energy complex of Ukraine. Scientific Journal of TNTU (Tern.). 2016. Vol. 83. No. 3. P. 144-153. [In Ukrainian].

2. Tarasenko M., Kozak K. Ways to save fuel and energy resources in daily graft. Scientific Journal of TNTU (Tern.). 2017. Vol. 85. No. 1. P. 101-108. [In Ukrainian].

3. Gotovych V., Nazarevych O., Shcherbak L. Mathematical modeling of the regular-mode electric power supply and electric power consumption processes of the organization. 2018. Scientific Journal of TNTU (Tern.). Vol. 91. No. 3. P. 134-142. DOI: https://doi.org/10.33108/visnyk_tntu2018.03.134

4. Saenko Iu. L., Popov A. S. Effektivnost primeneniia antirezonansnykh transformatorov napriazheniia kontrolia izoliatcii v setiakh s izolirovannoi neitraliu. Elektrifikatciia transportu. 2012. No. 4. P. 38-43. [In Russian].

5. Filippov M. A., Baraz V. R., Gervasiev M. A. Metodologija vybora metallicheskih splavov i uprochnjajushhih tehnologij v mashinostroenii: uchebnoe posobie: in 2 vol. Vol. II. Cvetnye metally i splavy. Yekaterinburg: Ural Universytet, 2013, 236 p. [In Russian].

6. Petrunina I. E. Spravochnik po pajke. Moskva: Mashinostroenie, 1984, 400 p. [In Russian].

7. Lashko N. F., Lashko S. V. Pajka metallov. 4 izd., dop. Moskva: Mashinostroenie, 1988, 376 p. [In Russian].

8. Maksimova S. V., Myasoid V. V. Vplyv osnovnogho materialu na strukturoutvorennja pajanykh shviv aljuminidiv nikelju i tytanu. Visnyk Pryazovsjkogho derzhavnogho tekhnichnogho universytetu. Seriia: Tekhnichni nauky. 2017. Issue 35. P. 92-98. [In Ukrainian].

9. Shulaev V. M., Listopad D. A., Karpenko A. V. Sovremennye vakuumnye elektropechi “OTTOM” TM i perspektivy ikh ispolzovaniia dlia vysokotemperaturnoi paiki izdelii iz vysokolegirovannykh stalei. Novi materialy i tekhnolohii v metalurhii ta mashynobuduvanni. 2013. No. 2.P. 88-92. [In Russian].

10. Krakhmalev O. V., Zinchenko O. I., Kovalevsky S. G., Kornienko A. V. Vplyv umov ekspluataciji na micnistj pajanykh z'jednanj. Visnyk Nacionaljnogho tekhnichnogho universytetu "KhPI”. Serija: Mashynoznavstvo ta SAPR, 2019. No. 1. P. 39-44. [In Ukrainian].

11. Gal'vanicheskie pokrytija v mashinostroenii: spravochnik / pod red. M. A. Schluger. Moskva: Mashinostroenie, 1985. Vol. 1. 240 p. [In Russian].

12. Sidelnikov S. B., Ber V. I., Orelkina T. A., Vagner A. V., Korobkin A. N. Razrabotka tekhnologicheskoi skhemy polucheniia tokosemnykh koletc iz berillievoi bronzy s pomoshchiu metodov listovoi shtampovki. Izvestiia MGTU “MAMI”, 2013. No. 2 (16), Vol. 2. P. 45-48.

13. Ermolaev G. V., Kvasnitsky V. V., Kvasnitsky V. F., Chigaryov V. V. Pajannja metaliv: pidruchnyk / za zah. red.V. F. Khorunova i V. F. Kvasnitsky. Mikolaev: NUK, 2015, 340 p. [In Ukrainian].

14. Lacedaemon A. V., Khryapin V. E. Spravochnik pajal'shhika. Moskva: Mashinostroenie, 1967, 328 p. [In Russian].

\section{Список використаної літератури}

1. Kapustyanskyi A., Varlamov G. Analysis of the fuel and energy complex of Ukraine. Scientific Journal of TNTU (Tern.). 2016. Vol. 83. No. 3. P. 144-153. [In Ukrainian].

2. Tarasenko M., Kozak K. Ways to save fuel and energy resources in daily graft. Scientific Journal of TNTU (Tern.). 2017. Vol. 85. No. 1. P. 101-108. [In Ukrainian].

3. Gotovych V., Nazarevych O., Shcherbak L. Mathematical modeling of the regular-mode electric power supply and electric power consumption processes of the organization. Scientific Journal of TNTU. Mathematical modeling. Mathematics. 2018. Vol. 91. No. 3. P. 134-142. DOI: https://doi.org/10.33108/visnyk_tntu2018.03.134

4. Саенко Ю. Л., Попов А. С. Эффективность применения антирезонансных трансформаторов напряжения контроля изоляции в сетях с изолированной нейтралью. Електрифікація транспорту. 2012. № 4. С. 38-43.

5. Филиппов М. А., Бараз В. Р., Гервасьев М. А. Методология выбора металлических сплавов и упрочняющих технологий в машиностроении: учебное пособие: в 2 т. Т. ІІ. Цветные металлы и сплавы. Екатеринбург: Урал. ун-т, 2013. 236 с.

6. Петрунина И. Е. Справочник по пайке. Москва: Машиностроение, 1984. 400 с.

7. Лашко Н. Ф., Лашко С. В. Пайка металлов: 4-е изд., доп. Москва: Машиностроение, 1988. 376 с.

8. Максимова С. В., М'ясоїд В. В. Вплив основного матеріалу на структуроутворення паяних швів алюмінідів нікелю і титану. Вісник Приазовського державного технічного університету. Серія: Технічні науки. 2017. Вип. 35. С. 92-98.

9. Шулаев В. М., Листопад Д. А., Карпенко А. В. Современные вакуумные электропечи «ОТТОМ» ТМ и перспективы их использования для высокотемпературной пайки изделий из высоколегированных сталей. Нові матеріали і технології в металургії та машинобудуванні. 2013. № 2. С. 88-92. 
10. Крахмальов О. В., Зінченко О. І., Ковалевський С. Г., Корнієнко О. В. Вплив умов експлуатації на міцність паяних 3'єднань. Вісник Національного технічного університету «ХПІ». Серія: Машинознавство та САПР. 2019. № 1. С. 39-44.

11. Гальванические покрытия в машиностроении: справочник, в 2-х т. / под ред. М. А. Шлугера. Москва: Машиностроение, 1985. Т. 1. 240 с.

12. Сидельников С. Б., Бер В. И., Орелкина Т. А., Вагнер А. В., Коробкин А. Н. Разработка технологической схемы получения токосъемных колец из бериллиевой бронзы с помощью методов листовой штамповки. Известия МГТУ «МАМИ». 2013. № 2 (16). Т. 2. С.45-48.

13. Єрмолаєв Г. В., Квасницький В. В., Квасницький В. Ф., Чигарьов В. В. Паяння металів: підручник / за заг. ред. В. Ф. Хорунова і В. Ф. Квасницького. Миколаїв: НУК, 2015. 340 с.

14. Лакедемонский А. В., Хряпин В. Е. Справочник паяльщика. Москва: Машиностроение, 1967. 328 с.

\title{
УДК 621.791.92
}

\section{РОЗРОБЛЕННЯ РЕСУРСОЗБЕРІГАЮЧОЇ ТА ЕКОЛОГІЧНО БЕЗПЕЧНОЇ ТЕХНОЛОГІЇ ПАЯННЯ БЕРИЛІЄВОЇ БРОНЗИ}

\section{Станіслав Бережний; Олексій Капустян; Руслан Куликовський; Ігор Авдєєв; Данило Урєкін}

\author{
Національний університет «Запорізька політехніка», Запоріжжся, Украӥна
}

\begin{abstract}
Резюме. Наведено результати дослідження можливості отримання нероз'ємного з'єднання берилієвої бронзи та срібла з використанням способу паяння. Розроблено технологічний процес виготовлення паяного силового високовольтного контакту роз'єднувача з берилієвої бронзи та срібної контактної пластини. Розроблено склад флюсу й технологію пічного паяння без використання вакууму та захисної атмосфери. Якість паяного з'єднання оиінювали: візуально; механічним випробуванням методом сколювання контактної пластини при дотичному ударному навантаженні; електричними випробуваннями - вимірювання перехідного опору й випробування на нагрівання. Обрано склад припою, який забезпечує необхідні технологічні властивості виробу, а саме електропровідність та механічну міцність спаю. Встановлено можливість проведення паяння берилієвої бронзи зі срібною контактною пластиною методом пічного паяння з використанням флюсів на основі солей $\mathrm{NaCl}: \mathrm{CaCl}_{2}: \mathrm{CaF}_{2}$ відповідно (24: 61 : 15\% мас) у середовищі атмосфери. Показано можливість паяння берилісвої бронзи БрБ2 у середовищі атмосфери з використанням дослідного флюсу на базі евтектики системи $\mathrm{NaCl}-\mathrm{CaCl}_{2}$ (28...72\% мас.) із додаванням $15 \% \mathrm{CaF}_{2}$ по шару міді. Розроблено технологію паяння берилієвої бронзи БрБ2 зі срібними контактними пластинами срібним припоєм ПСр68. Процес паяння поєднано з операцією гартування, що дозволяе уникнути додаткової термічної операції; залишки флюсу видаляються при гартуванні і фактично не потребують додаткової операиії очищення; застосовані припій, компоненти флюсу та технології нанесення шару міді не дефіцитні та відносно дешеві, що дозволяє суттєво знизити собівартість виробу при дотриманні вимог технічного завдання. Розроблений технологічний прочес дозволяе відмовитися від використання вакуумних установок $і$ токсичних флюсів, щฺо відповідає екологічно безпечній технології паяння берилісвої бронзи.
\end{abstract}

Ключові слова: бронза берилієва; паяння; припій; флюс; покриття; ресурсозберігаюча технологія; екологічна безпека. 